\title{
Fedmeepidemien - vi må begynne med barna
}

Verdens helseorganisasjon (WHO) har observert en urovekkende og rask global økning av overvekt og fedme hos barn de siste 20-30 årene. Organisasjonen har beregnet at det finnes 22 millioner barn under fem år som er overvektige eller fete (1). Overvekt i barne- og ungdomsår gir økt risiko for overvekt i voksen alder, og risikoen øker jo eldre og mer overvektig barnet er (2). I tillegg gir høy kroppsmasseindeks (BMI) i barneårene økt risiko for hjerte- og karsykdommer i voksen alder (3).

Ifølge Folkehelseinstituttet lider $15-20 \%$ av norske barn i alderen 8-12 år av overvekt eller fedme (4). Vi mangler imidlertid gode representative, longitudinelle data som kan gi oss et sikkert svar på om den globale fedmeepidemien hos barn også er kommet til Norge. Katrine Dvergsnes \& Guri Skeies artikkel i dette nummer av Tidsskriftet, der de beskriver vektutviklingen hos fireåringer i Tromsø over en periode på 25 år, gir oss ny og viktig kunnskap (5). Overraskende nok finner forfatterne ingen statistisk signifikant endring i gjennomsnittlig kroppsmasseindeks. Det negative funnet kan ha flere forklaringer, inkludert studiens retrospektive design, enkelte metodologiske svakheter og manglende statistisk styrke. Det at nullhypotesen (ingen endring i BMI) ikke kunne forkastes, betyr imidlertid ikke at den er sann - hvilket delvis støttes av studiens positive funn.

For det første er andelen overvektige jenter blitt mer enn doblet fra 1976 til 2001, dernest har andelen overvektige jenter vært omtrent dobbelt så stor som andelen overvektige gutter det siste tiåret (5).

En studie av overvektige 13-åringer viste at disse barna allerede fra 2-3 års alder hadde høyere vektøkning enn jevnaldrende (6). Jentene i studien passerte BMI-grensen for overvekt ved fem års alder, guttene ved åtte års alder. Dette indikerer at overvektsutviklingen starter tidligere hos jentene og kan forklare høyere forekomst av overvekt hos jenter enn hos gutter ved fire års alder. Spørsmålet om hvorvidt den høyere forekomsten av overvekt hos fireårige jenter delvis kan forklare den kjente overhyppigheten av fedme hos kvinner, er imidlertid ikke avklart.

Kunnskapsgrunnlaget om effekten av forskjellige forebyggende og terapeutiske tiltak mot overvekt og fedme hos barn er begrenset. Det er imidlertid generell enighet om at det er viktig å fange opp eventuelle tendenser til utvikling av overvekt hos førskolebarn og samtidig gi familie og omsorgspersoner konkret støtte og veiledning om individuelle tiltak. Små, realistiske endringer vil kunne bidra til vektstabilisering, slik at barnet gjennom fysiologisk høydetilvekst oppnår gradvis redusert overvekt. Kommunenes helsestasjoner fungerer allerede som gode arenaer for slike endringssamtaler. Hvorvidt endringer kan gjennomføres, har imidlertid også sammenheng med familiens totale livssituasjon og i hvilken grad husholdningen har kunnskapsmessige, økonomiske, psykiske og sosiale forutsetninger til å endre vaner. Det er derfor behov for utstrakt tverrfaglig og tverretatlig samarbeid dersom man skal lykkes med målrettet forebyggende endringsarbeid i familier.

Endringer i levevaner er krevende, særlig dersom samfunnets organisering ikke stimulerer til det. Det er derfor også nødvendig med overordnede, strukturelle tiltak for å begrense omfanget av fedme og fedmerelaterte sykdommer hos norske barn (7). Prispolitiske virkemidler vil kunne bidra til økt inntak av sunn mat med høyt innhold av fiber, vitaminer og mineraler. Minst like viktig er det å legge til rette for økt aktivitet i miljøene der barn og ungdom ferdes. Mye tyder på at inaktivitet er en større medisinsk utfordring enn fedme. Fysisk aktivitet beskytter mot sykdom, uavhengig av kroppsform og -størrelse (7). I tillegg er fysisk aktivitet en kilde til glede, livsutfoldelse og positive opplevelser av å mestre noe. Grunnlaget for livslange aktivitetsvaner etableres i tidlige barneår. Det å gjennomføre konkrete tiltak for å øke aktivitetsnivået fra småbarnsalderen av vil derfor kunne gi helsegevinst både på kort og på lang sikt.

Måling av høyde og vekt (og beregning av BMI) på forskjellige aldersnivåer utføres i en rekke land. Dette gir mulighet til individuell oppfølging av vekstutvikling og risiko for sykdom. I tillegg er populasjonsbasert overvåking av BMI-trender en god indikator på effekten av individuelle og samfunnsbaserte tiltak for å bedre befolkningens levevaner. Med vår infrastruktur har vi nå i Norge en unik mulighet til å iverksette gode individuelle og generelle tiltak som kan bidra til å gi barna et mindre fedmefremmende oppvekstmiljø. Det bør samtidig etableres et nasjonalt medisinsk kvalitetsregister med sikte på å følge og evaluere effekten av forskjellige tiltak. Et kvalitetsregister vil kunne gi oss kunnskap om effekten av populasjonsbasert overvåking samt ny kunnskap om hvilke tiltak som er mest effektive for å forebygge og behandle fedme hos barn og unge. Dersom registeret gjøres personidentifiserbart, vil det også kunne benyttes til å analysere sammenhenger mellom utvikling av overvekt og eksempelvis forhold knyttet til svangerskap og fødsel (Medisinsk fødselsregister), kreft (Kreftregisteret) og dødelighet (Dødsårsaksregisteret). Grundige etiske overveielser må inngå i planleggingen av et slikt register.

\section{Martin Handeland \\ martin.handeland@siv.no \\ Jøran Hjelmesæth \\ joran.hjelmeseth@siv.no}

Martin Handeland (f. 1965) leder seksjon for barn og unge ved Senter for sykelig overvekt i Helse Sør-Øst i Tønsberg. Han ledet Helsedirektoratets arbeidsgruppe for utarbeiding av nasjonale faglige retningslinjer for forebygging, utredning og behandling av overvekt og fedme hos barn og unge.

Jøran Hjelmesæth (f. 1957) er spesialist $i$ indremedisin og nyresykdommer og leder av den tverrfaglige poliklinikken og forskningsprogrammet ved Senter for sykelig overvekt i Helse Sør-Øst.

\section{Oppgitte interessekonflikter: Ingen}

\section{Litteratur}

1. World Health Organization. Childhood overweight and obesity. www.who.int/ dietphysicalactivity/childhood/en/ (23.11.2008)

2. Magarey AM, Daniels LA, Boulton TJ et al. Predicting obesity in early adulthood from childhood and parental obesity. Int J Obes Relat Metab Disord 2003; 27 505-13.

3. Baker JL, Olsen LW, Sorensen TIA. Childhood body-mass index and the risk of coronary heart disease in adulthood. N Engl J Med 2007; 357: 2329-37.

4. Folkehelseinstituttet. Overvekt og fedme hos barn og unge - faktaark. www. fhi.no/artikler?id=70852 (23.11.2008).

5. Dvergsnes K, Skeie G. Utviklingen i kroppsmasseindeks hos fireåringer Tromsø 1980-2005. Tidsskr Nor Legeforen 2009: 129: 13-6.

6. Lagstrom H, Hakanen M, Niinikoski H et al. Growth patterns and obesity development in overweight or normal-weight 13-year-old adolescents: the STRIP Study. Pediatrics 2008; 122: e876-83.

7. Lee DC, Sui X, Blair SN. Does physical activity ameliorate health hazards of obesity? Br J Sports Med 2008; e-publisert 29.10.2008. 